Supporting information

\title{
Förster Resonance Energy Transfer-Based Fluorescent Probe for the Selective Imaging of Hydroxylamine in Living Cells
}

Baoli Dong, Minggang Tian, Xiuqi Kong, Wenhui Song, Yaru Lu and Weiying Lin*

Institute of Fluorescent Probes for Biological Imaging, School of Chemistry and Chemical Engineering, School of Materials Science and Engineering, University of Jinan, Jinan, Shandong 250022, People's Republic of China

E-mail: weiyinglin2013@163.com 


\section{Table of Contents}
page

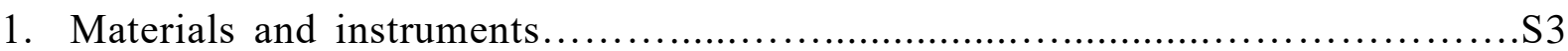

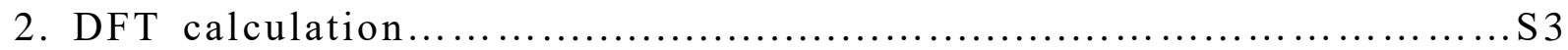

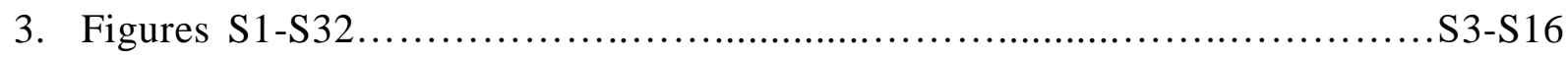

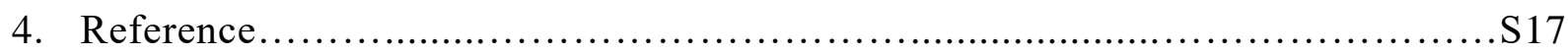


Materials and instruments: All solvents and reagents were commercially available and used without further purification. Doubly distilled water was used in all the experiments. Thinlayer chromatography (TLC) analysis was performed on silica gel plates and column chromatography was conducted over silica gel (mesh 200-300), both of which were purchased from the Qingdao Ocean Chemicals. Xanthine oxidase from bovine milk was pruchased Sigma Company. Fluorescence spectra and relative fluorescence intensity were measured with a Hitachi F-4600 spectrofluorimeter with a $10 \mathrm{~mm}$ quartz cuvette. UV/vis spectra were obtained with a Shimadzu UV-2700 spectrophotometer. High-resolution mass spectra (HRMS) for the characterization of structures were collected using a Bruker apex-Ultra mass spectrometer (Bruker Daltonics Corp., USA) in electrospray ionization (ESI) mode. ${ }^{1} \mathrm{H}$ and ${ }^{13} \mathrm{C}$ NMR spectra were recorded on an AVANCE III $400 \mathrm{MHz}$ Digital NMR Spectrometer, using DMSO- $\mathrm{d}_{6}$ as solvent and tetramethylsilane (TMS) as internal reference. Liquid chromatography/mass spectrometry (LC-MS) analysis was performed from Agilent 6400 series Triple Quadrupole using an ESI mass spectrometer.

DFT calculation ${ }^{[1]}$ : The ground state structure of the probe was optimized using DFT with B3LYP functional and 6-31G basis set with Gaussian 09 software.

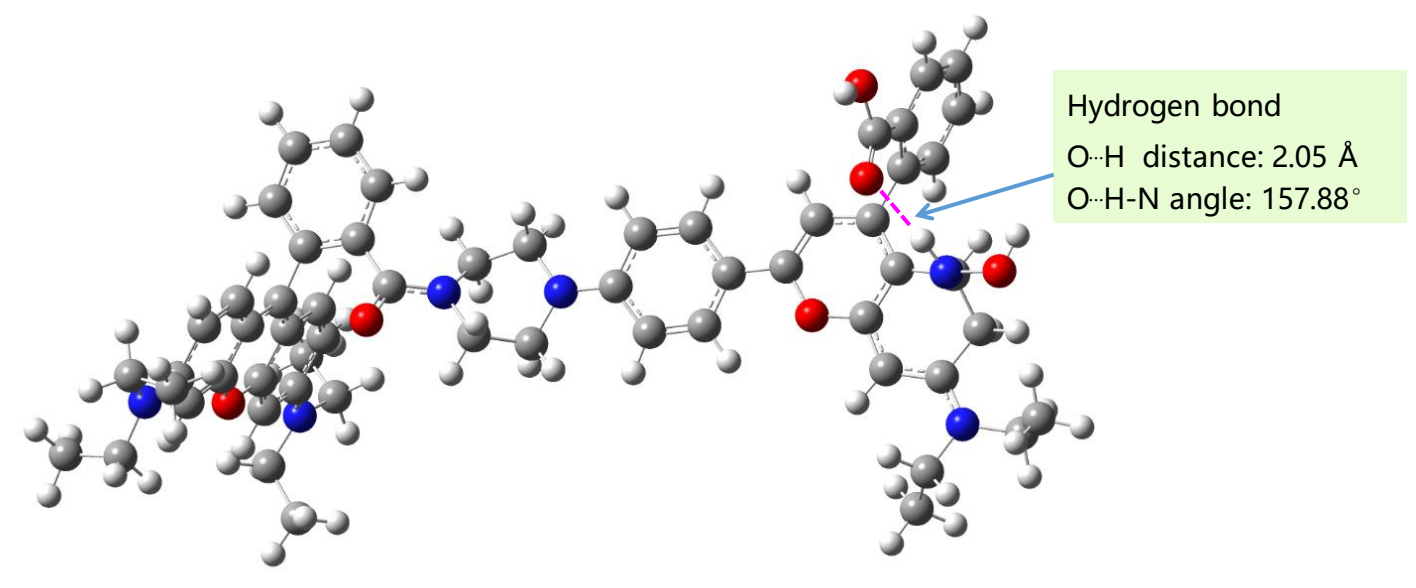

Figure S1 DFT optimized structure of RhChr-HA. In the ball-and-stick representation, carbon, nitrogen, oxygen and hydrogen atoms are colored in gray, blue, red and light gray, respectively. 


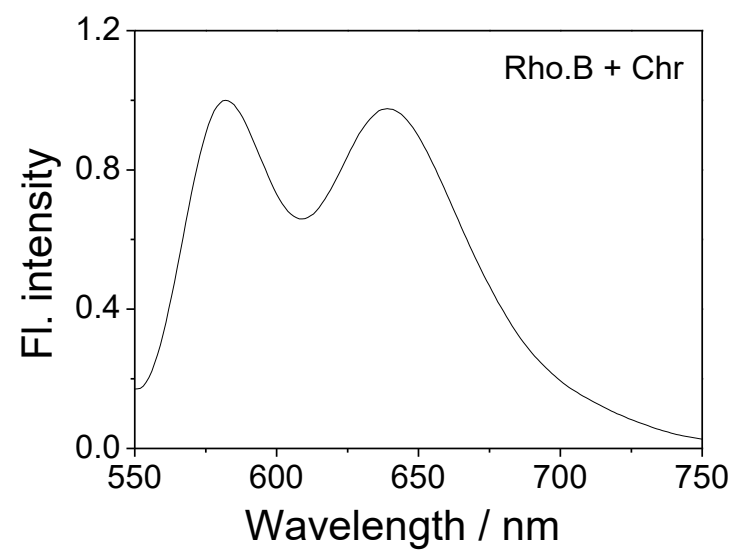

Figure S2 Normalized fluorescence spectra of the mixture of $5 \mu \mathrm{M}$ rhodamine B (Rho. B) and compound Chr. $\lambda_{\mathrm{ex}}=540 \mathrm{~nm}$.
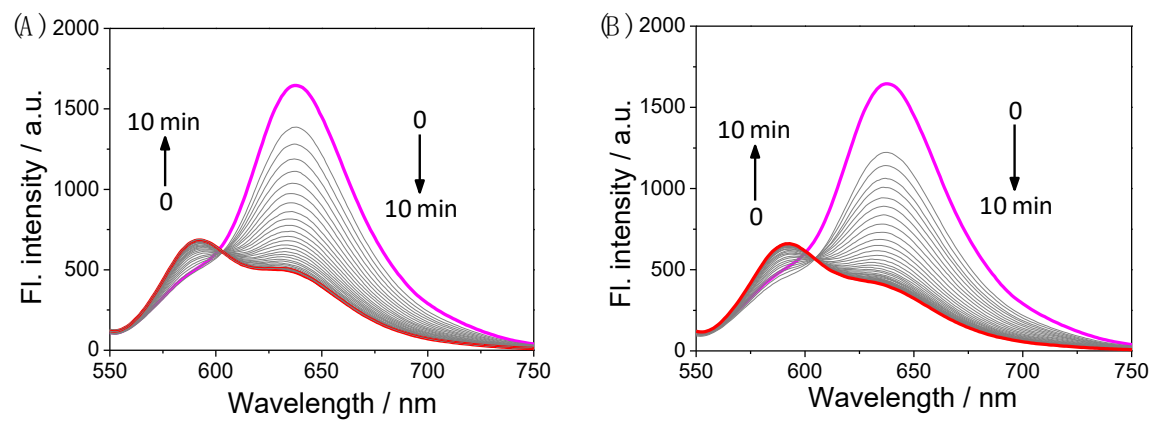

Figure S3 Time-dependent fluorescence spectra of $5 \mu \mathrm{M} \mathbf{R h C h r}$ in the presence of $100 \mu \mathrm{M}$ (A) or $150 \mu \mathrm{M}$ (B) HA in PBS (pH = 7.4, 20\% EtOH, $20 \mathrm{mM}$ ). $\lambda_{\mathrm{ex}}=540 \mathrm{~nm}$.
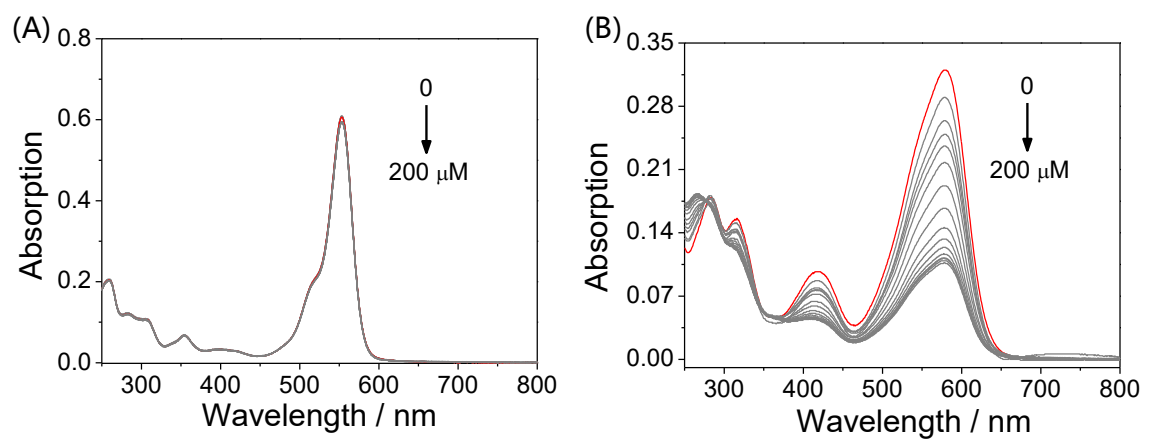

Figure S4 Absorption spectra of $5 \mu \mathrm{M}$ Rhodamine B (A) and compound Chr (B) in absence or presence of HA with different concentrations in PBS ( $\mathrm{pH}=7.4,20 \% \mathrm{EtOH}, 20 \mathrm{mM})$.
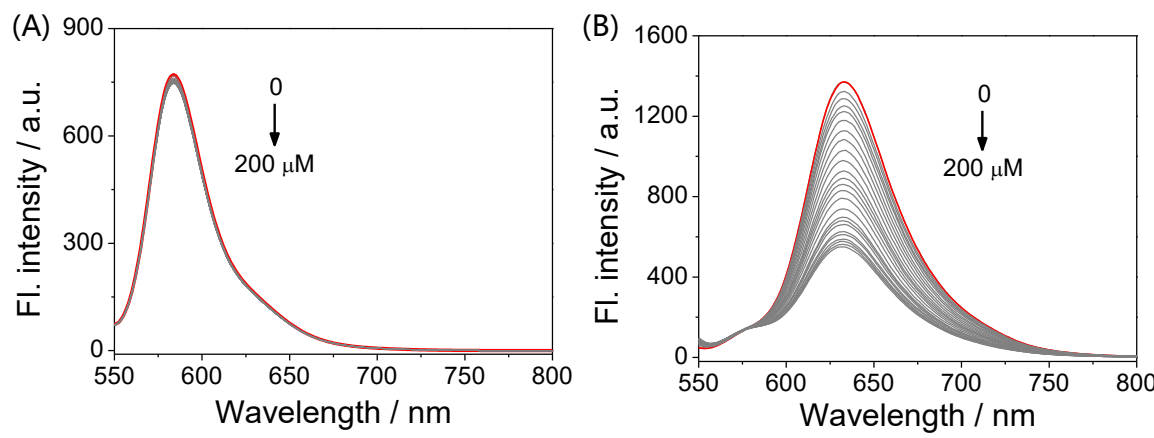
Figure S5 Fluorescence spectra of $5 \mu \mathrm{M}$ Rhodamine B (A) and compound Chr (B) in presence of HA with different concentrations in PBS ( $\mathrm{pH}=7.4,20 \% \mathrm{EtOH}, 20 \mathrm{mM}) . \lambda_{\mathrm{ex}}=$ $540 \mathrm{~nm}$.

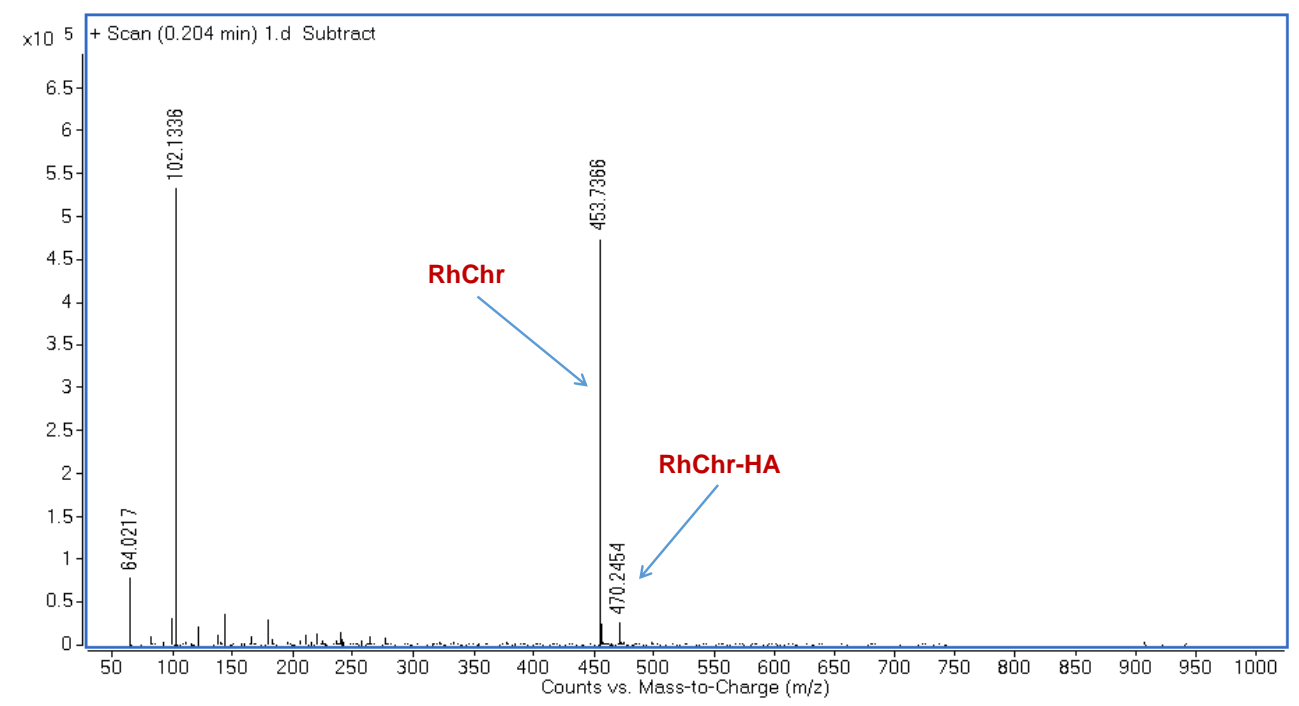

Figure S6 HRMS data of the product of the probe $\mathbf{R h C h r}$ with HA (10 equiv.) in PBS (pH = 7.4, 20\% EtOH, $20 \mathrm{mM}$ ) at room temperature for $10 \mathrm{~min}$.

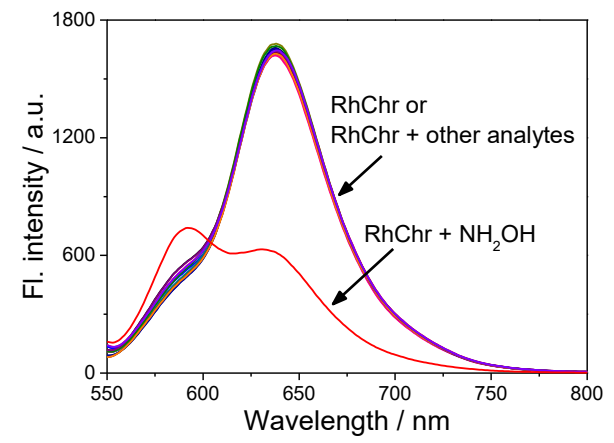

Figure S7 Fluorescence spectra of $5 \mu \mathrm{M}$ RhChr treated with various species in PBS ( $\mathrm{pH}=$ 7.4, 20\% EtOH, $20 \mathrm{mM}) . \lambda_{\mathrm{ex}}=540 \mathrm{~nm}$.
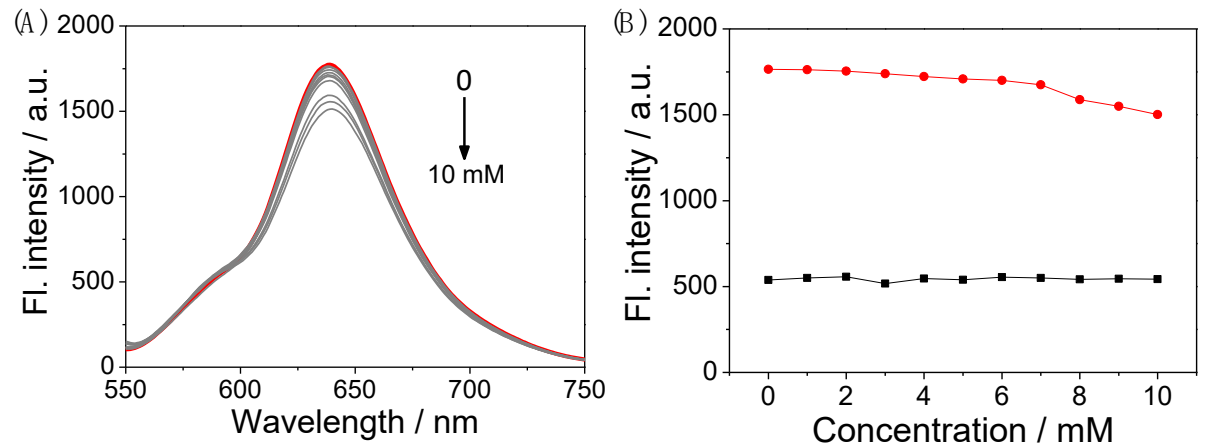

Figure S8 Fluorescence spectra (A) and fluorescence intensity (B: $590 \mathrm{~nm}$, black; $637 \mathrm{~nm}$, red) of $5 \mu \mathrm{M}$ RhChr treated with GSH $(0-10 \mathrm{mM})$ in PBS ( $\mathrm{pH}=7.4,20 \% \mathrm{EtOH}, 20 \mathrm{mM})$. $\lambda_{\mathrm{ex}}=540 \mathrm{~nm}$. 

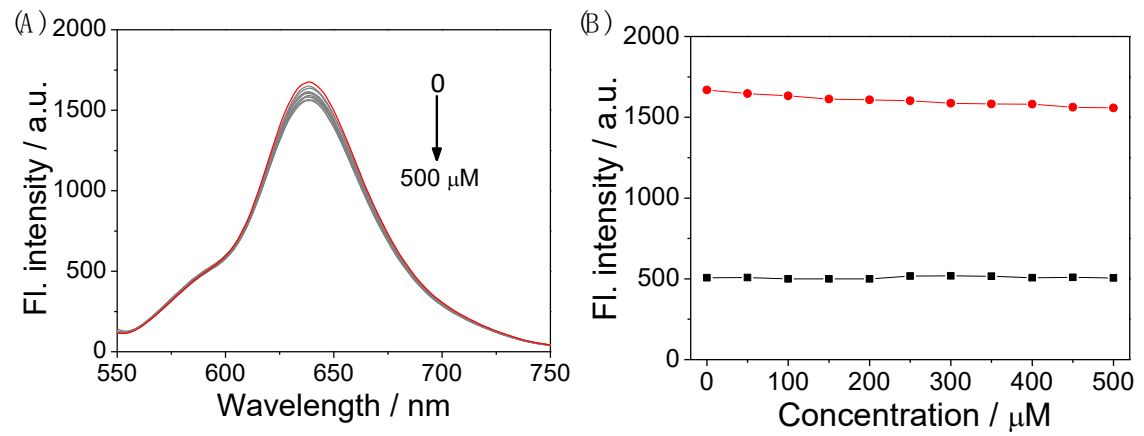

Figure S9 Fluorescence spectra (A) and fluorescence intensity (B: $590 \mathrm{~nm}$, black; $637 \mathrm{~nm}$, red) of $5 \mu \mathrm{M}$ RhChr treated with $\mathrm{Na}_{2} \mathrm{~S}(0-500 \mu \mathrm{M})$ in PBS $(\mathrm{pH}=7.4,20 \% \mathrm{EtOH}, 20 \mathrm{mM})$. $\lambda_{\mathrm{ex}}=540 \mathrm{~nm}$.
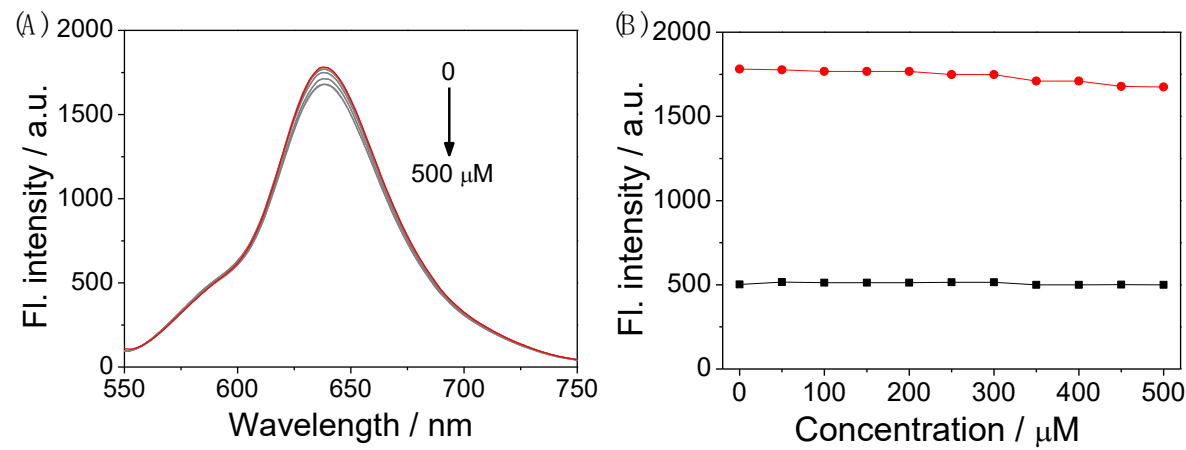

Figure S10 Fluorescence spectra (A) and fluorescence intensity (B: $590 \mathrm{~nm}$, black; $637 \mathrm{~nm}$, red) of $5 \mu \mathrm{M}$ RhChr treated with $\mathrm{Na}_{2} \mathrm{SO}_{3}(0-500 \mu \mathrm{M})$ in PBS $(\mathrm{pH}=7.4,20 \% \mathrm{EtOH}, 20 \mathrm{mM})$. $\lambda_{\mathrm{ex}}=540 \mathrm{~nm}$.
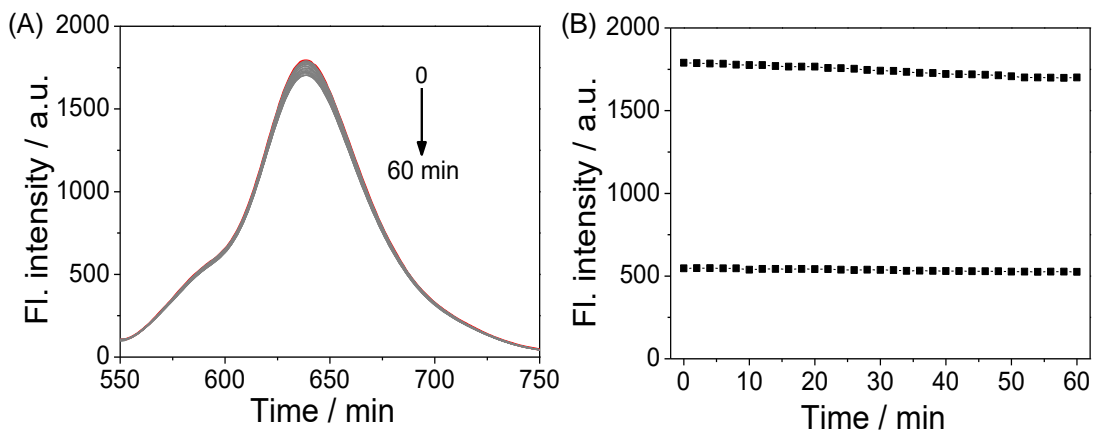

Figure S11 Time-spectra fluorescence spectra (A) and fluorescence intensity (B: $590 \mathrm{~nm}$, black; $637 \mathrm{~nm}$, red) of $5 \mu \mathrm{M}$ RhChr treated with $1 \mathrm{mM} \mathrm{GSH}$ in PBS $(\mathrm{pH}=7.4,20 \% \mathrm{EtOH}$, $20 \mathrm{mM}) . \lambda_{\mathrm{ex}}=540 \mathrm{~nm}$. 

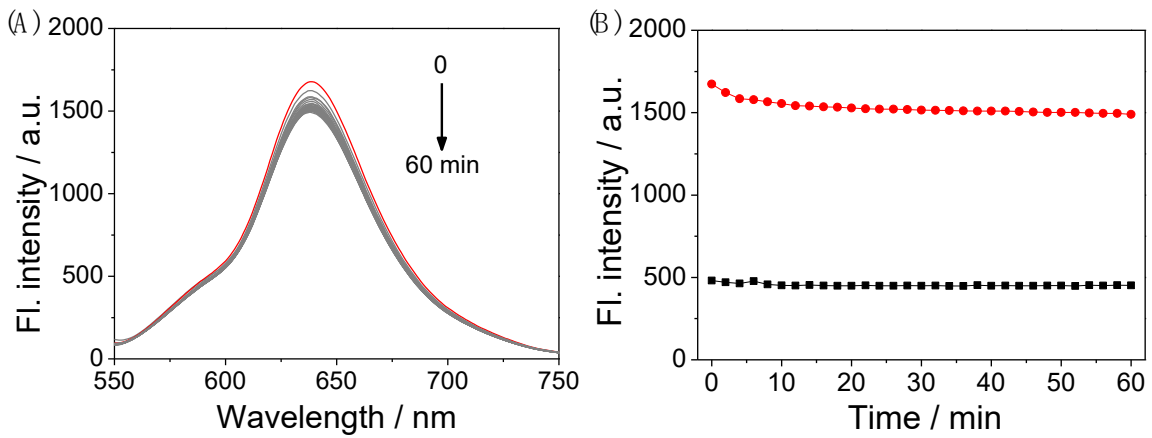

Figure S12 Time-spectra fluorescence spectra (A) and fluorescence intensity (B: $590 \mathrm{~nm}$, black; $637 \mathrm{~nm}$, red) of $5 \mu \mathrm{M}$ RhChr treated with $200 \mu \mathrm{M} \mathrm{Na} 2 \mathrm{~S}$ in PBS (pH = 7.4, 20\% EtOH, $20 \mathrm{mM}) . \lambda_{\mathrm{ex}}=540 \mathrm{~nm}$.
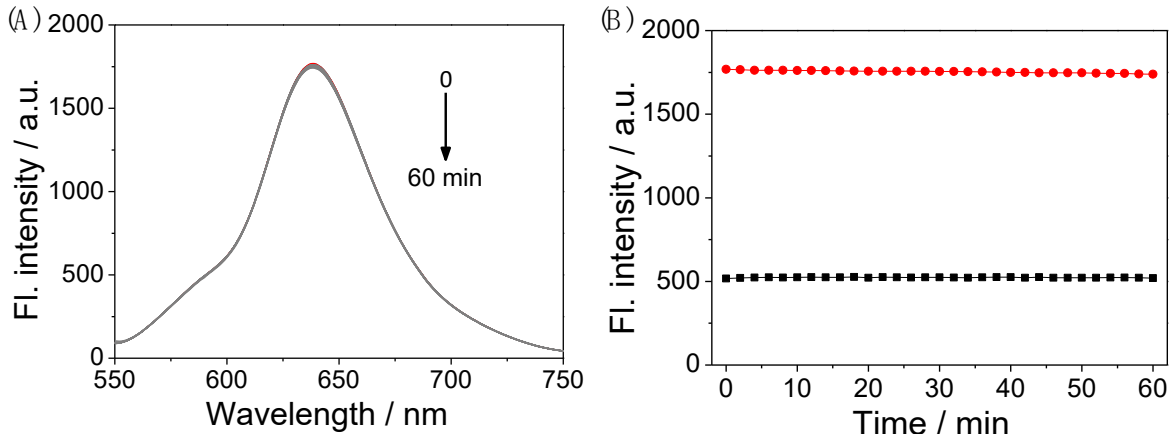

Figure S13 Time-spectra fluorescence spectra (A) and fluorescence intensity (B: $590 \mathrm{~nm}$, black; $637 \mathrm{~nm}$, red) of $5 \mu \mathrm{M}$ RhChr treated with $200 \mu \mathrm{M} \mathrm{Na} \mathrm{SO}_{3}$ in $\mathrm{PBS}$ ( $\mathrm{pH}=7.4,20 \%$ $\mathrm{EtOH}, 20 \mathrm{mM}) . \lambda_{\mathrm{ex}}=540 \mathrm{~nm}$.
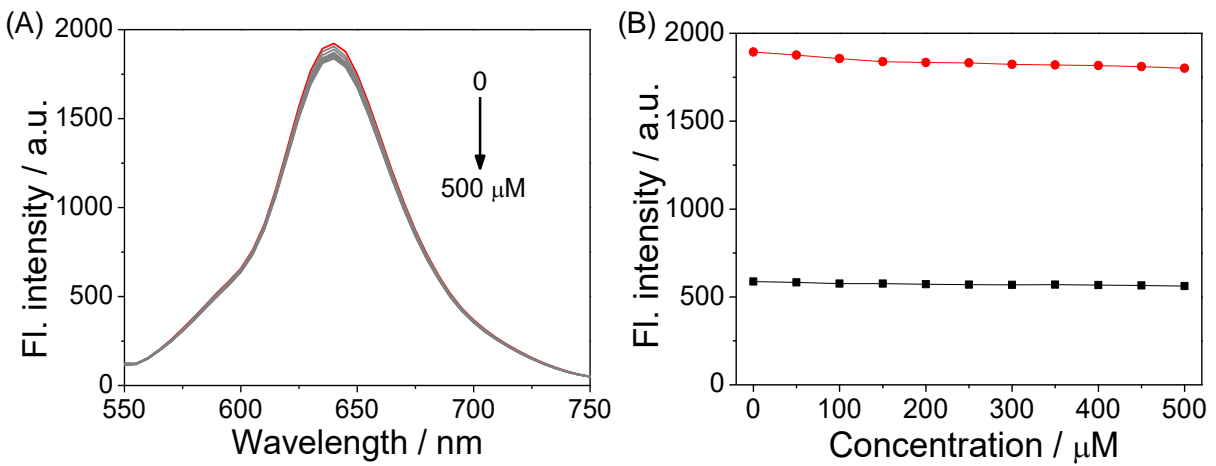

Figure S14 Fluorescence spectra (A) and fluorescence intensity (B: $590 \mathrm{~nm}$, black; $637 \mathrm{~nm}$, red) of $5 \mu \mathrm{M}$ RhChr treated with $\mathrm{NH}_{3}(0-500 \mu \mathrm{M})$ in PBS $(\mathrm{pH}=7.4,20 \% \mathrm{EtOH}, 20 \mathrm{mM})$. $\lambda_{\mathrm{ex}}=540 \mathrm{~nm}$. 

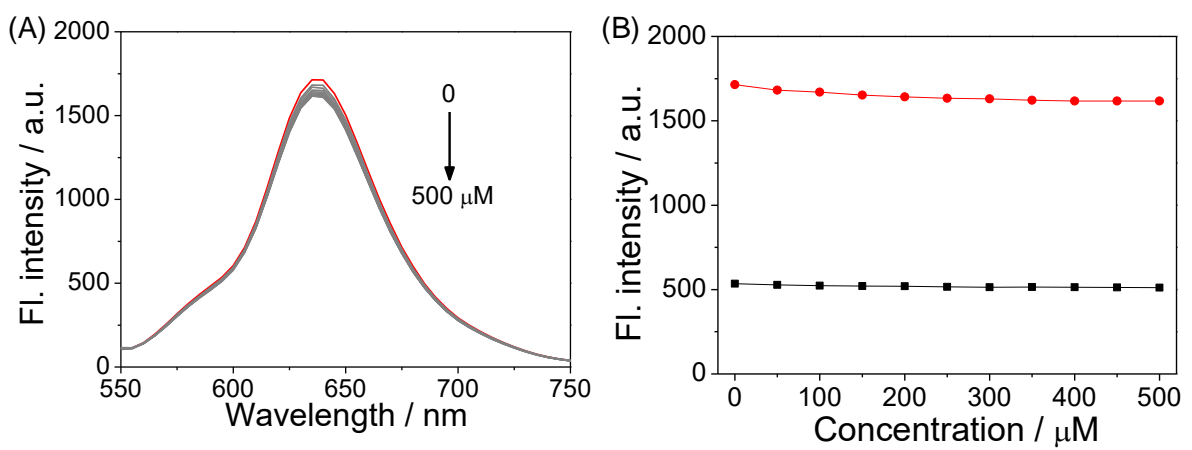

Figure S15 Fluorescence spectra (A) and fluorescence intensity (B: $590 \mathrm{~nm}$, black; $637 \mathrm{~nm}$, red) of $5 \mu \mathrm{M}$ RhChr treated with $\mathrm{NH}_{4}{ }^{+}(0-500 \mu \mathrm{M})$ in PBS $(\mathrm{pH}=7.4,20 \% \mathrm{EtOH}, 20 \mathrm{mM})$. $\lambda_{\mathrm{ex}}=540 \mathrm{~nm}$.
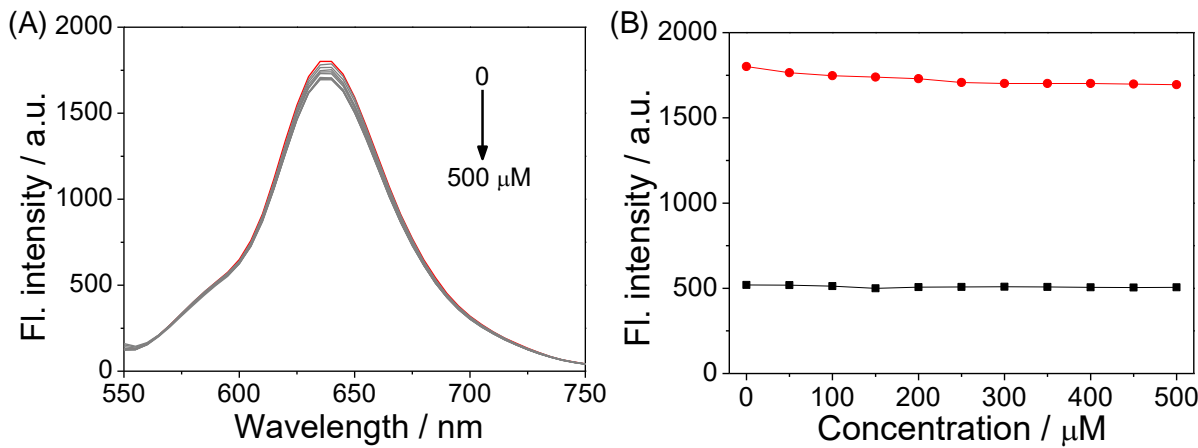

Figure S16 Fluorescence spectra (A) and fluorescence intensity (B: $590 \mathrm{~nm}$, black; $637 \mathrm{~nm}$, red) of $5 \mu \mathrm{M} \mathbf{R h C h r}$ treated with L-arginine $(0-500 \mu \mathrm{M})$ in $\mathrm{PBS}(\mathrm{pH}=7.4,20 \% \mathrm{EtOH}, 20$ $\mathrm{mM}) . \lambda_{\mathrm{ex}}=540 \mathrm{~nm}$.
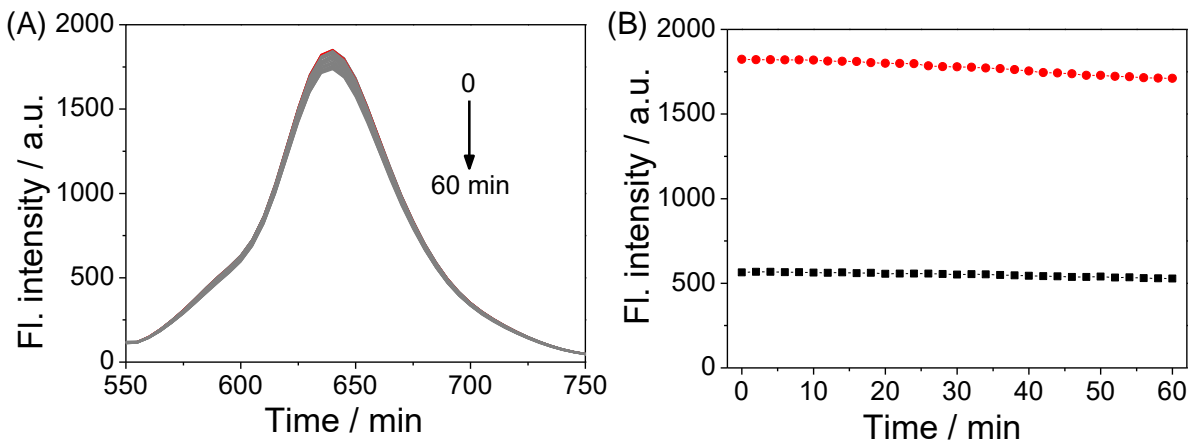

Figure S17 Time-spectra fluorescence spectra (A) and fluorescence intensity (B: $590 \mathrm{~nm}$, black; $637 \mathrm{~nm}$, red) of $5 \mu \mathrm{M}$ RhChr treated with $200 \mu \mathrm{M} \mathrm{NH}_{3}$ in $\mathrm{PBS}(\mathrm{pH}=7.4,20 \% \mathrm{EtOH}$, $20 \mathrm{mM}) . \lambda_{\mathrm{ex}}=540 \mathrm{~nm}$. 

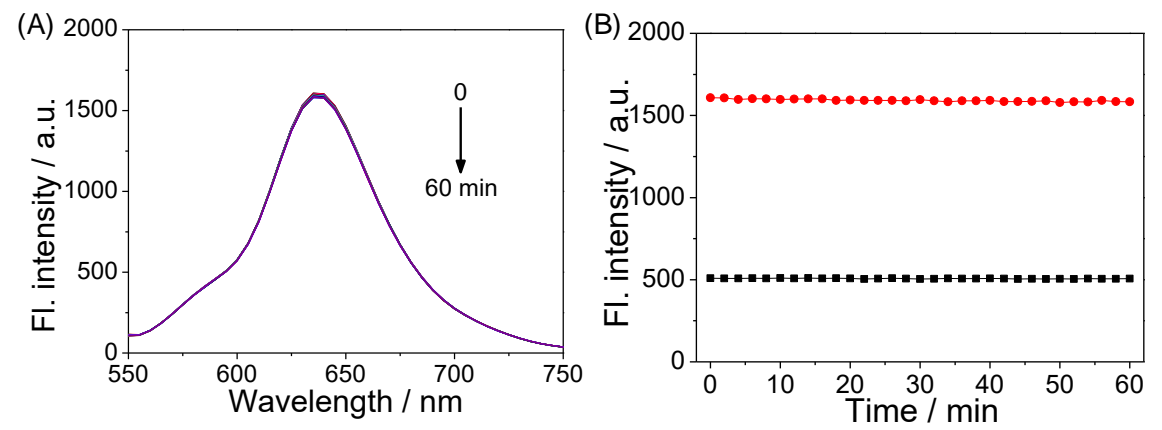

Figure S18 Time-spectra fluorescence spectra (A) and fluorescence intensity (B: $590 \mathrm{~nm}$, black; $637 \mathrm{~nm}$, red) of $5 \mu \mathrm{M}$ RhChr treated with $200 \mu \mathrm{M} \mathrm{NH}_{4}{ }^{+}$in $\mathrm{PBS}(\mathrm{pH}=7.4,20 \% \mathrm{EtOH}$, $20 \mathrm{mM}) . \lambda_{\mathrm{ex}}=540 \mathrm{~nm}$.
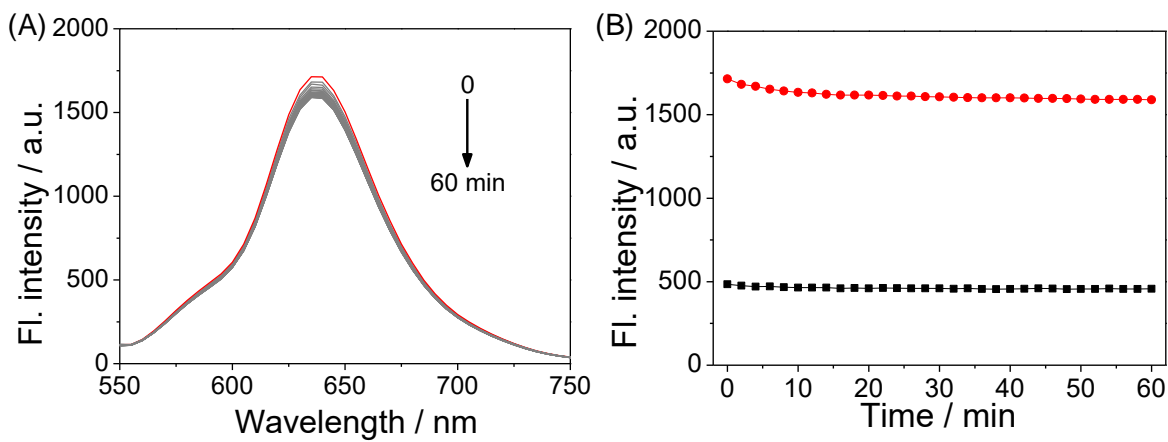

Figure S19 Time-spectra fluorescence spectra (A) and fluorescence intensity (B: $590 \mathrm{~nm}$, black; $637 \mathrm{~nm}$, red) of $5 \mu \mathrm{M}$ RhChr treated with $200 \mu \mathrm{M}$ L-arginine in PBS (pH = 7.4, 20\% EtOH, $20 \mathrm{mM}) . \lambda_{\mathrm{ex}}=540 \mathrm{~nm}$.
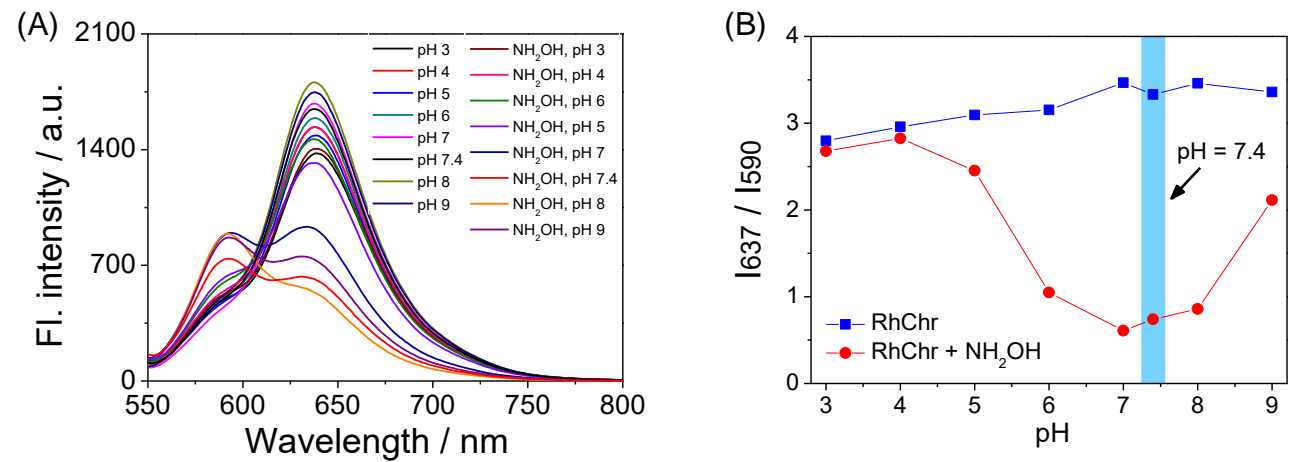

Figure S20 Fluorescence spectra (A) and fluorescence intensity ratios $\left(\mathrm{I}_{637} / \mathrm{I}_{590}\right)(\mathrm{B})$ of $5 \mu \mathrm{M}$ $\mathbf{R h C h r}$ in absence or presence of $100 \mu \mathrm{M}$ HA at various $\mathrm{pH}$ conditions. $\lambda_{\mathrm{ex}}=540 \mathrm{~nm}$. 

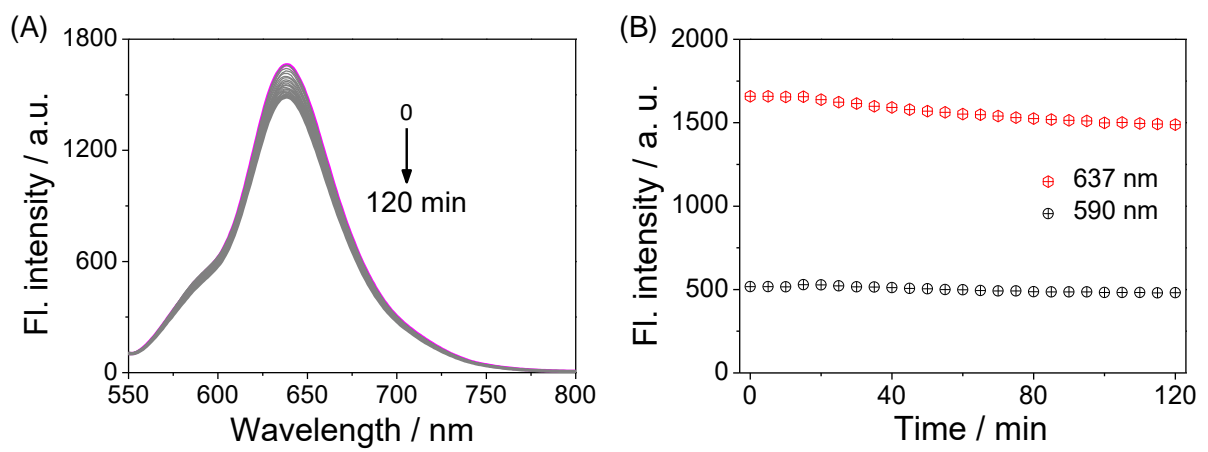

Figure S21 Time-dependent fluorescence spectra (A) and fluorescence intensity (B: $590 \mathrm{~nm}$, black; $637 \mathrm{~nm}$, red) of $\mathbf{R h C h r}$ in PBS (pH = 7.4, 20\% EtOH, $20 \mathrm{mM}$ ) under ceaseless irradiation. $\lambda_{\mathrm{ex}}=540 \mathrm{~nm}$.

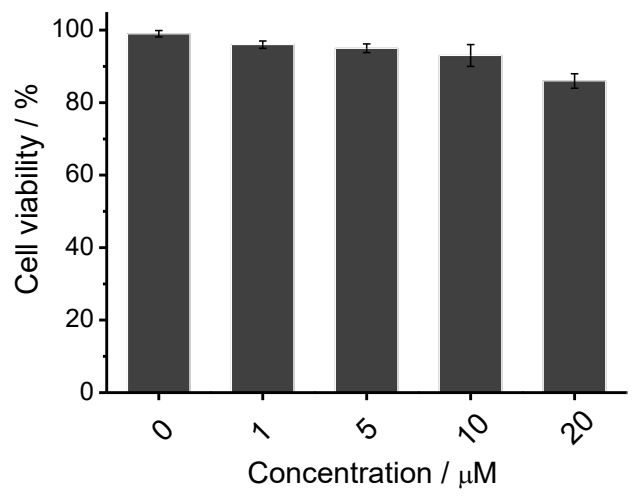

Figure S22 Survival of HepG2 cells in the presence of $\mathbf{R h C h r}$ at various concentrations measured using MTT assay.
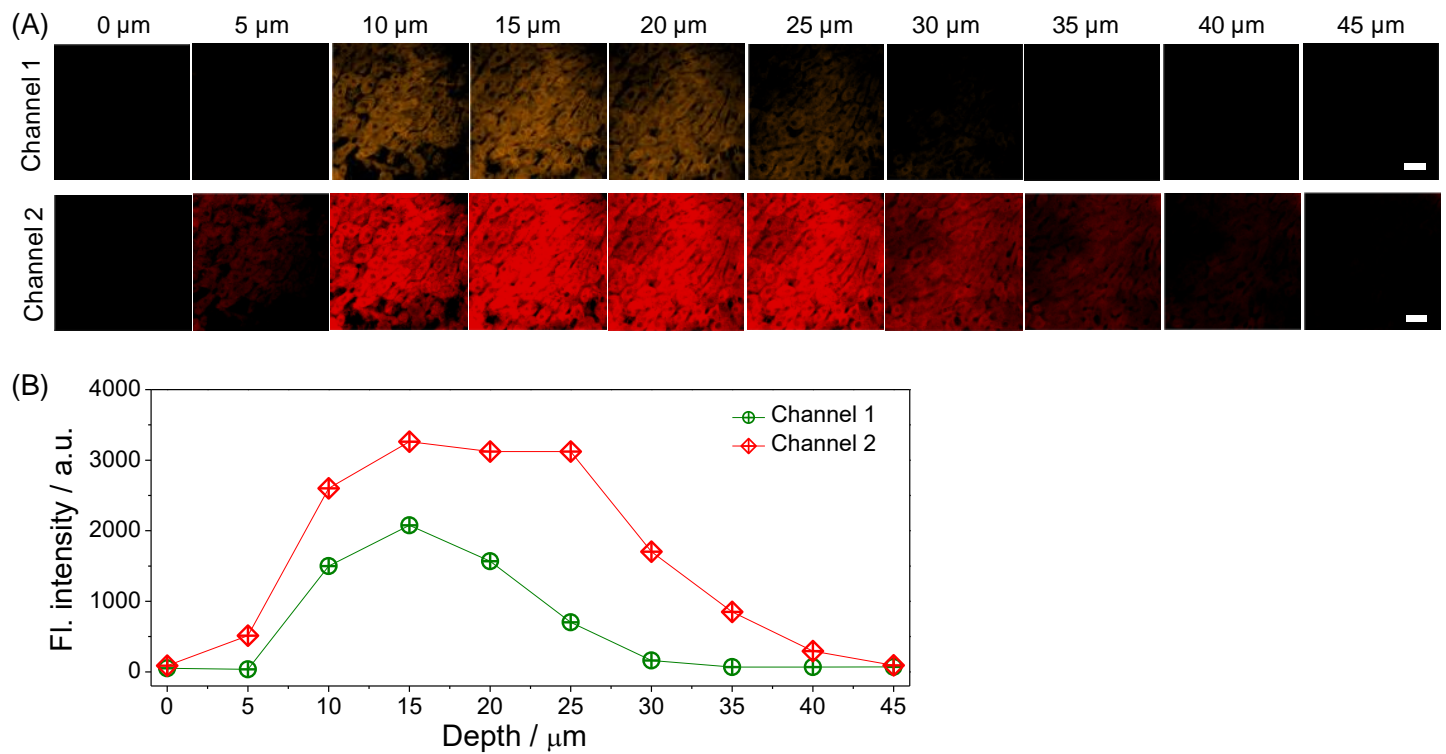

Figure S23 (A) Imaging of the liver tissue from liver tissues stained with $5 \mu \mathrm{M} \mathbf{R h C h r}$ for 30 min. Channel 1, $\lambda_{\mathrm{em}}=570-620 \mathrm{~nm}$; Channel 2, $\lambda_{\mathrm{em}}=663-738 \mathrm{~nm}$. Scale bar $=50 \mu \mathrm{m}$. (B) Quantified relative fluorescence intensities in Channel 1 and Channel 2 at various penetration depths. 

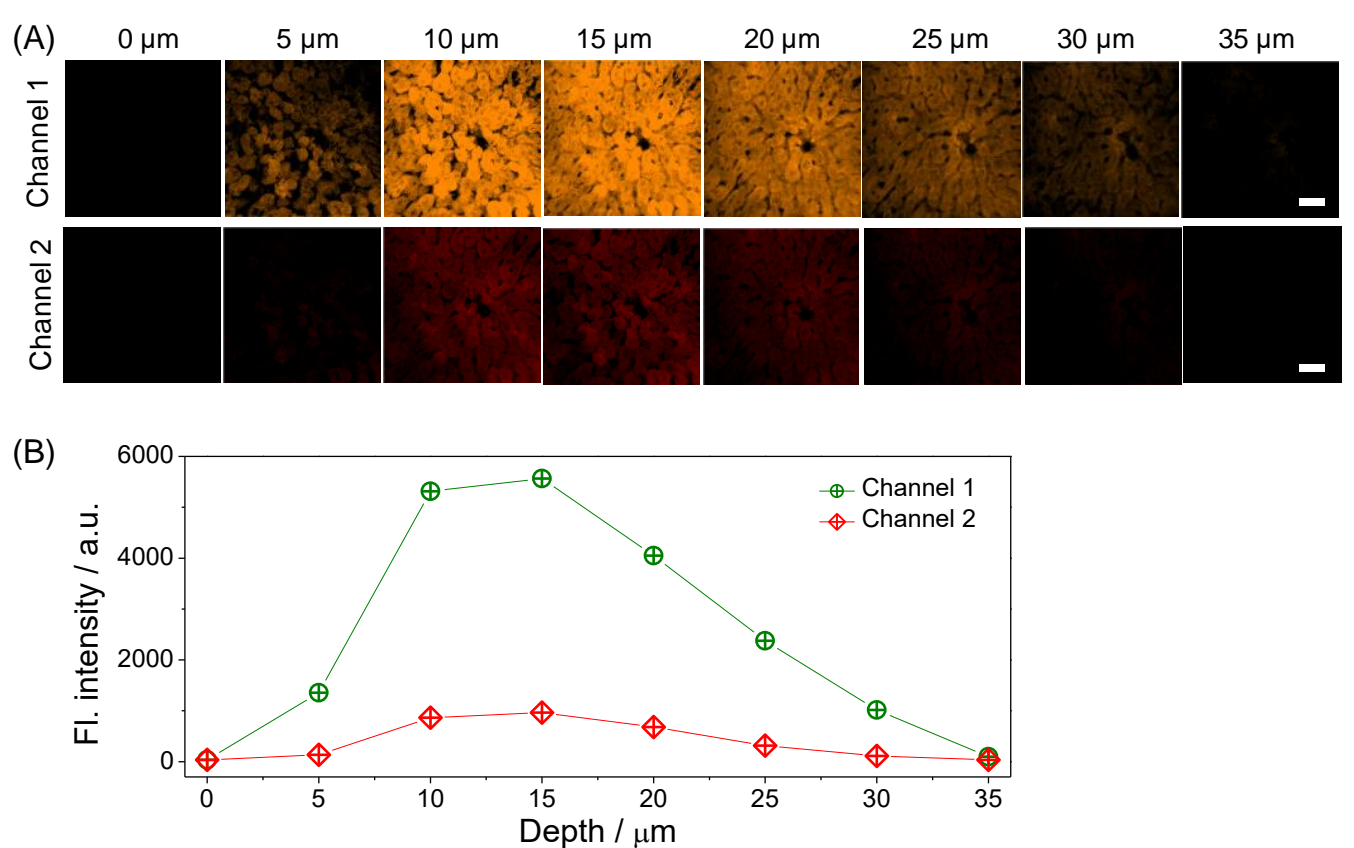

Figure S24 (A) Imaging of the liver tissue from liver tissues stained with $5 \mu \mathrm{M} \mathbf{R h C h r}$ for 30 min and further treated with $100 \mu \mathrm{M}$ HA for $30 \mathrm{~min}$. Channel $1, \lambda_{\mathrm{em}}=570-620 \mathrm{~nm}$; Channel 2 , $\lambda_{\text {em }}=663-738 \mathrm{~nm}$. Scale bar $=50 \mu \mathrm{m}$. (B) Quantified relative fluorescence intensities in Channel 1 and Channel 2 at various penetration depths.

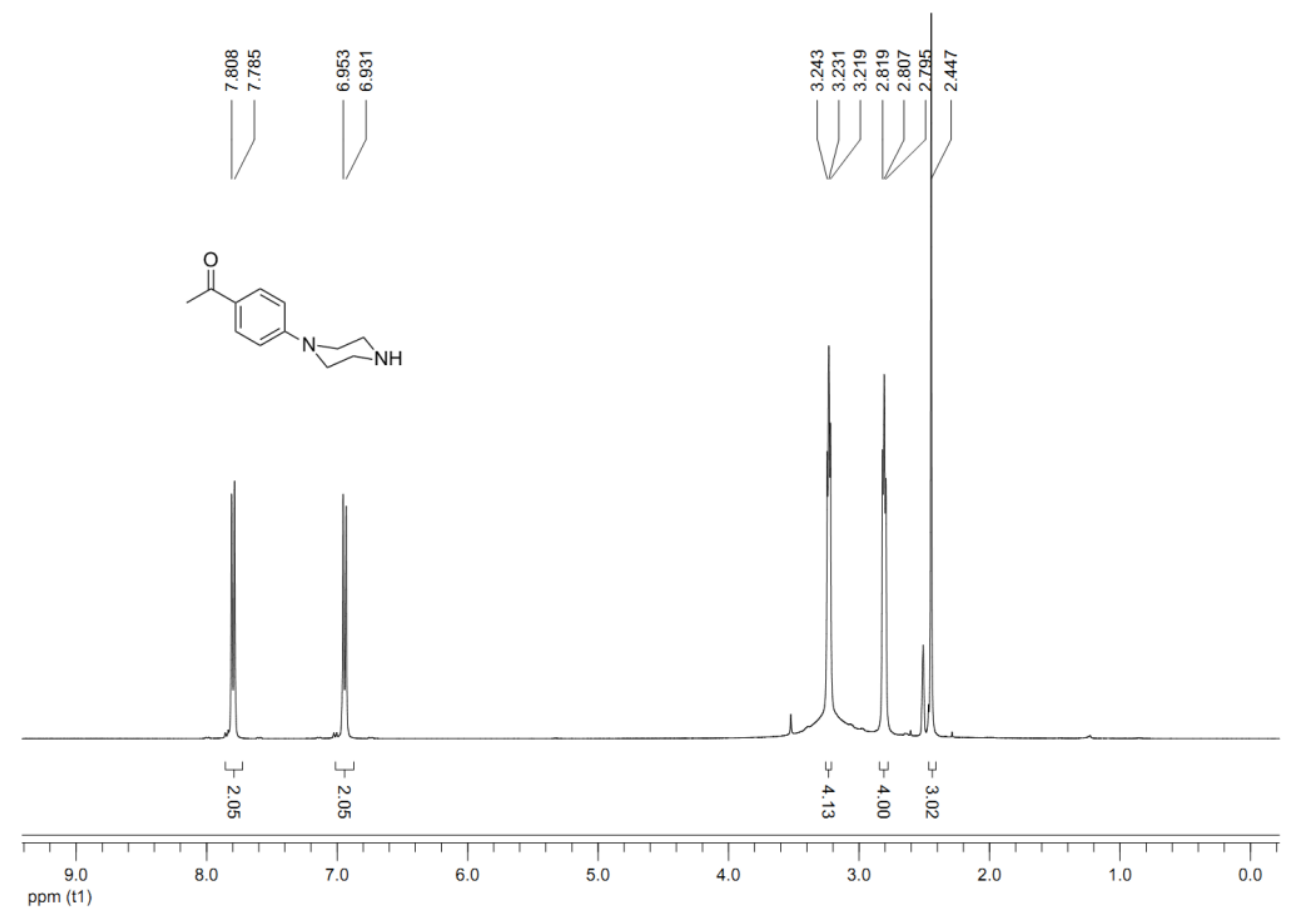

Figure S25 ${ }^{1}$ H NMR data of 1-(4-(piperazin-1-yl)phenyl)ethanone (DMSO- $d_{6}$ ). 


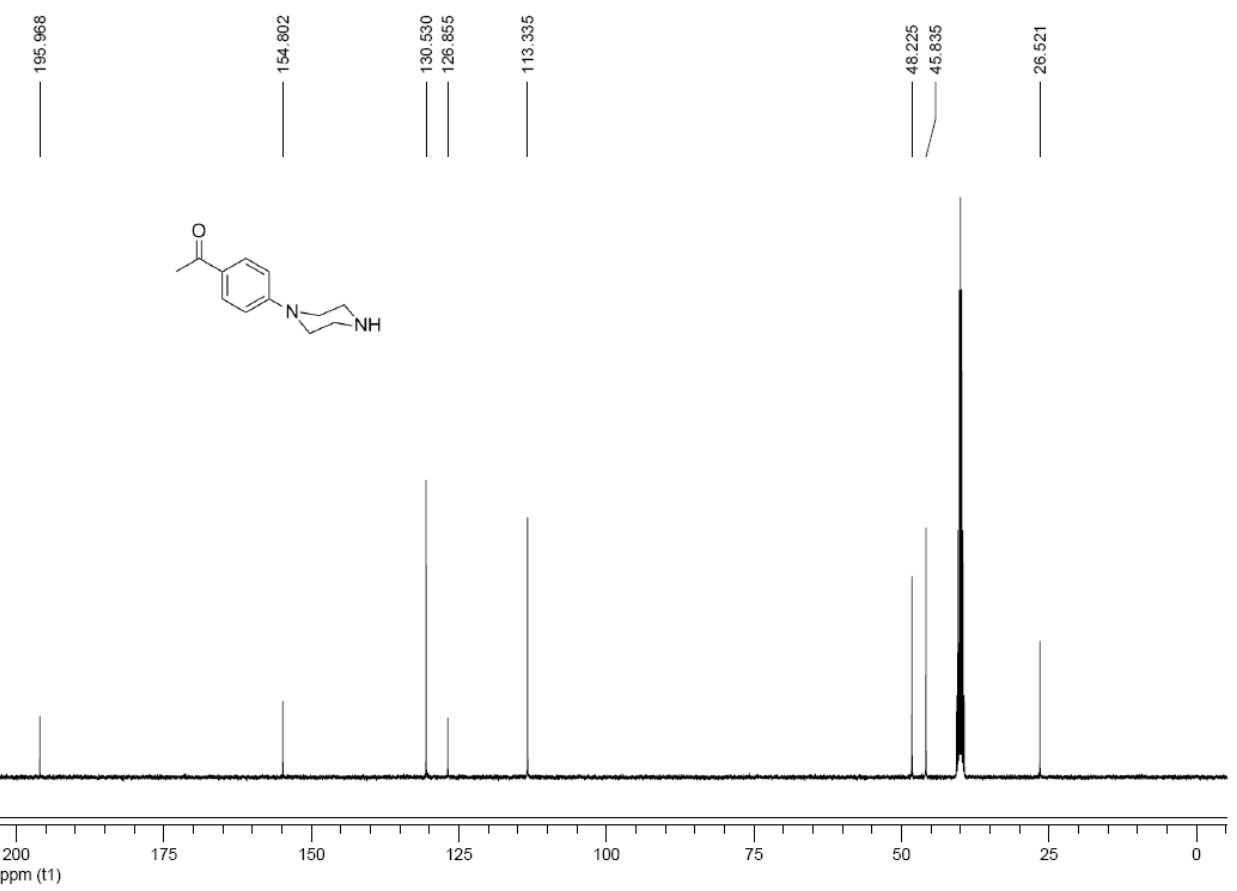

Figure S26 ${ }^{13}$ C NMR data of 1-(4-(piperazin-1-yl)phenyl)ethanone (DMSO- $\left.d_{6}\right)$. 
(A)

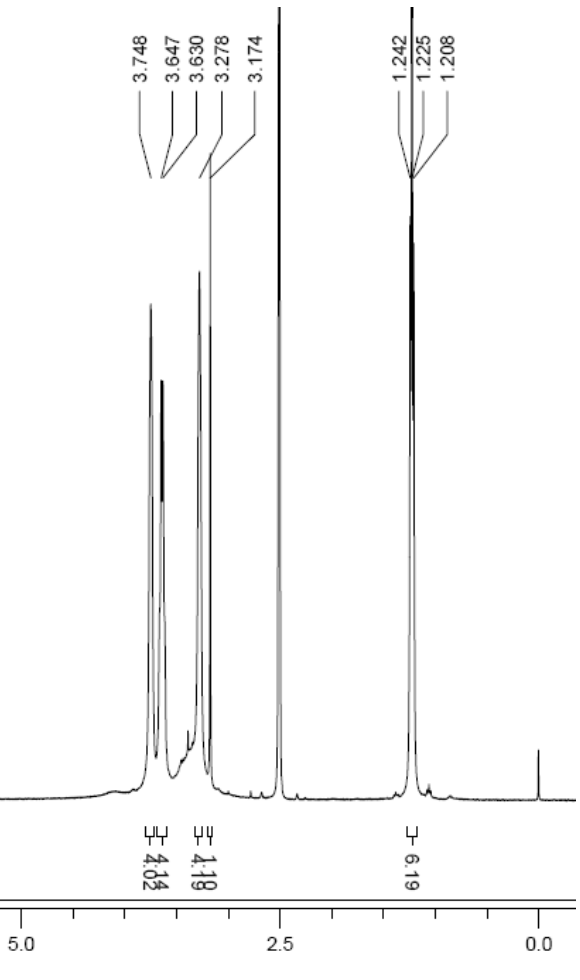

(B)
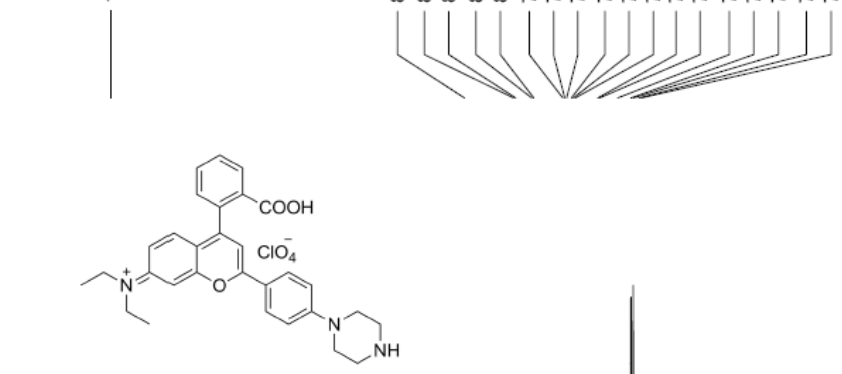

ppm (t1)
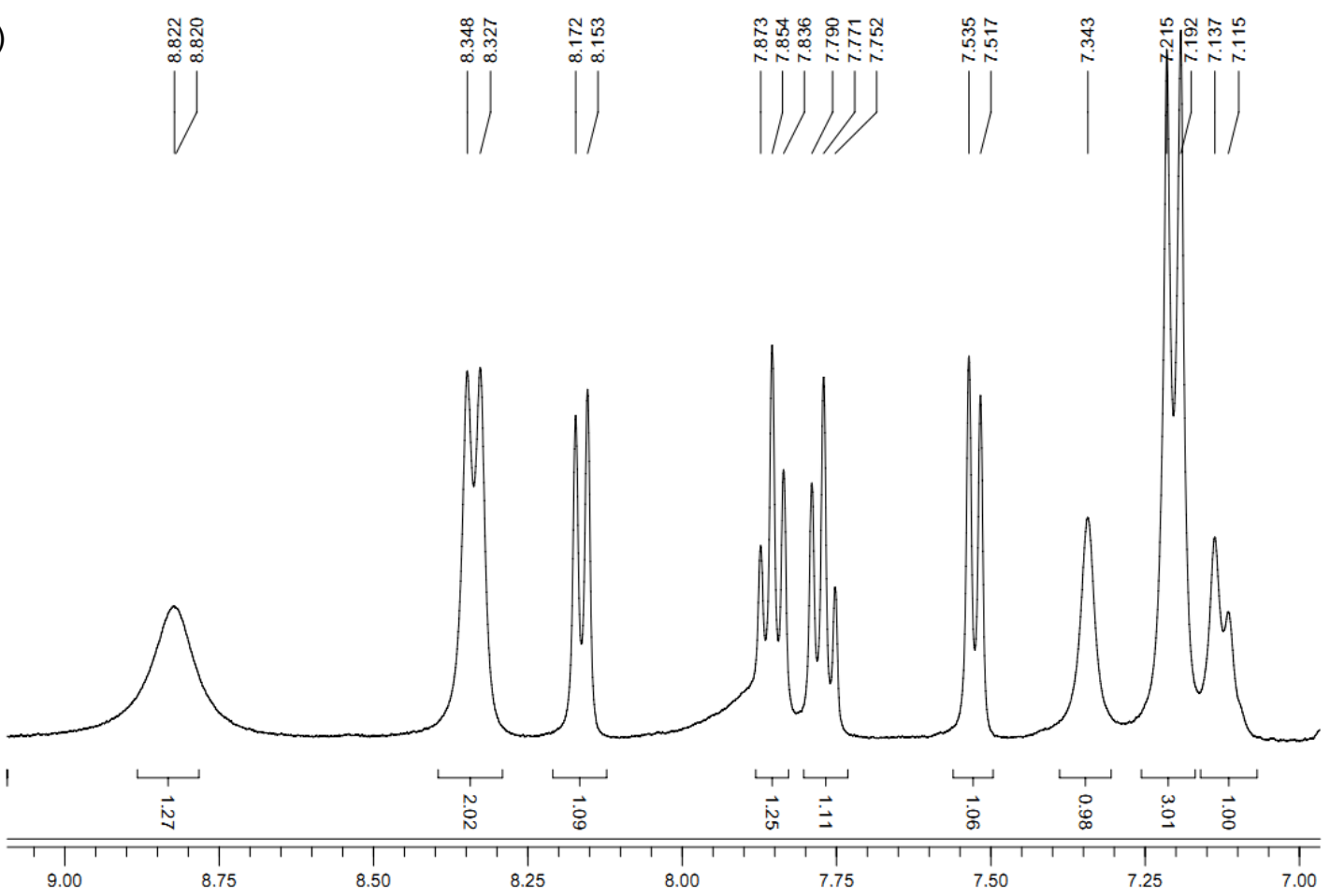

Figure S27 (A) ${ }^{1} \mathrm{H}$ NMR data of compound Chr (DMSO-d d . (B) Amplified ${ }^{1} \mathrm{H}$ NMR data of compound $\mathrm{Chr}\left(\mathrm{DMSO}_{6} \mathrm{~d}_{6}\right)$ in the aromatic region. 


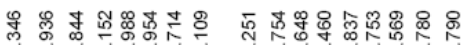

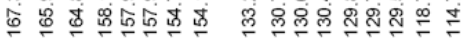

$(1|1| j|1| 1 \mid j)$

官
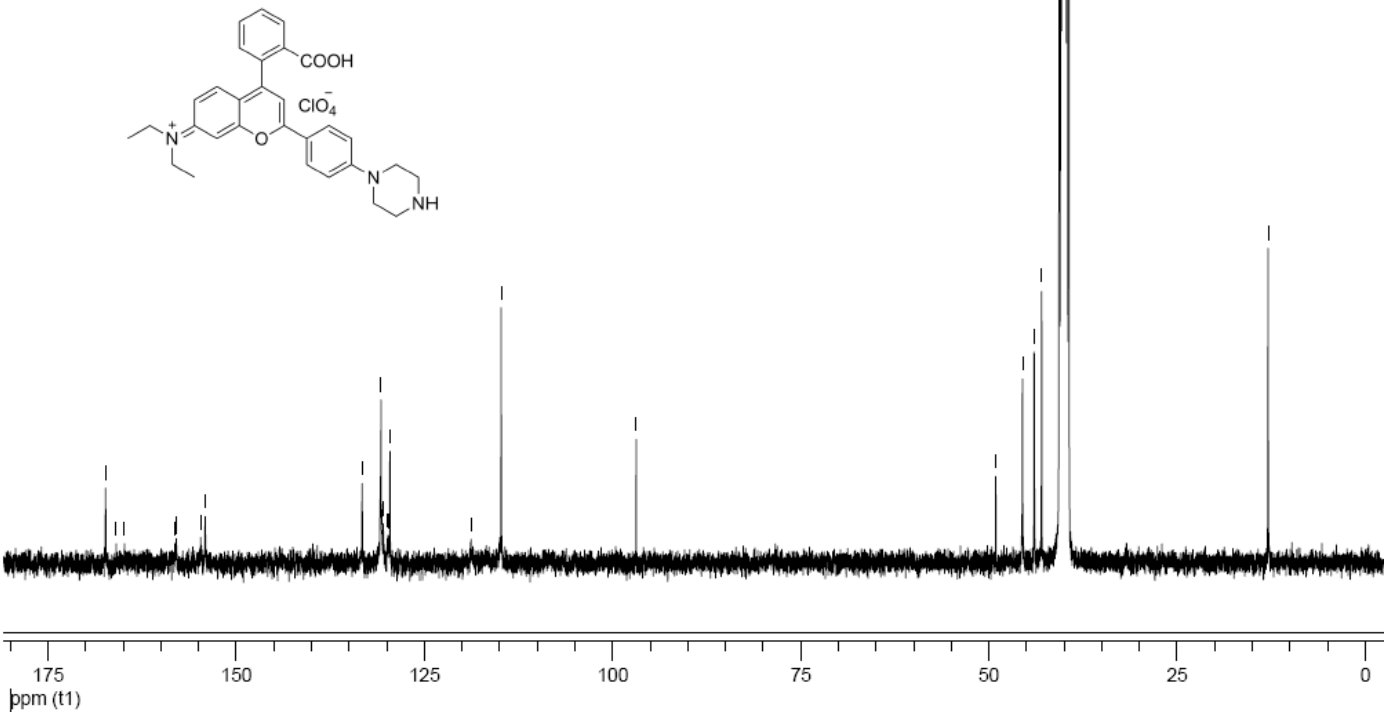

Figure S28 ${ }^{13} \mathrm{C}$ NMR data of compound $\mathrm{Chr}\left(\mathrm{DMSO}-\mathrm{d}_{6}\right)$.

(A) HPLC data

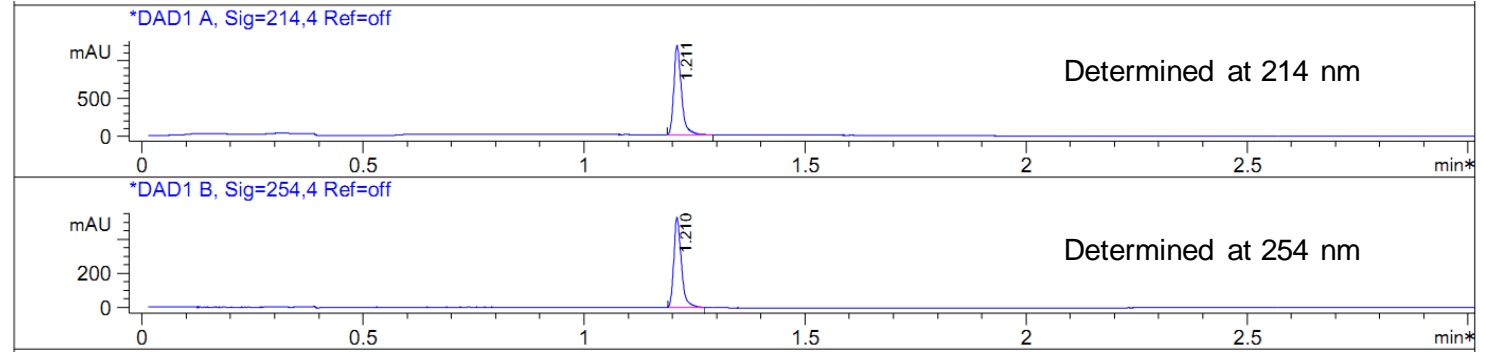

(B) MS data

Ret. Time: $1.21 \quad<<<$ POSITIVE SPECTRA $>>>$

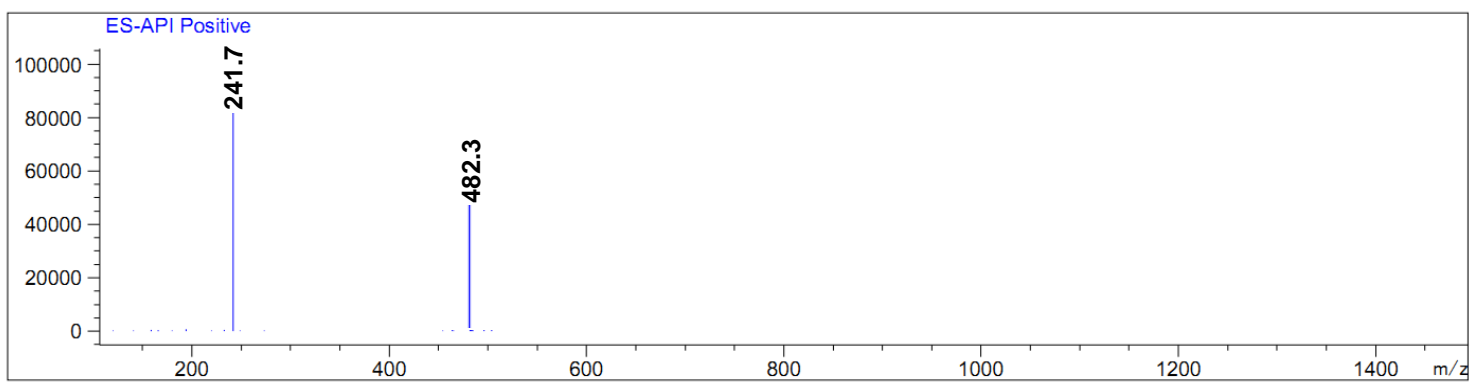

Figure S29 LC-MS data of compound Chr. 

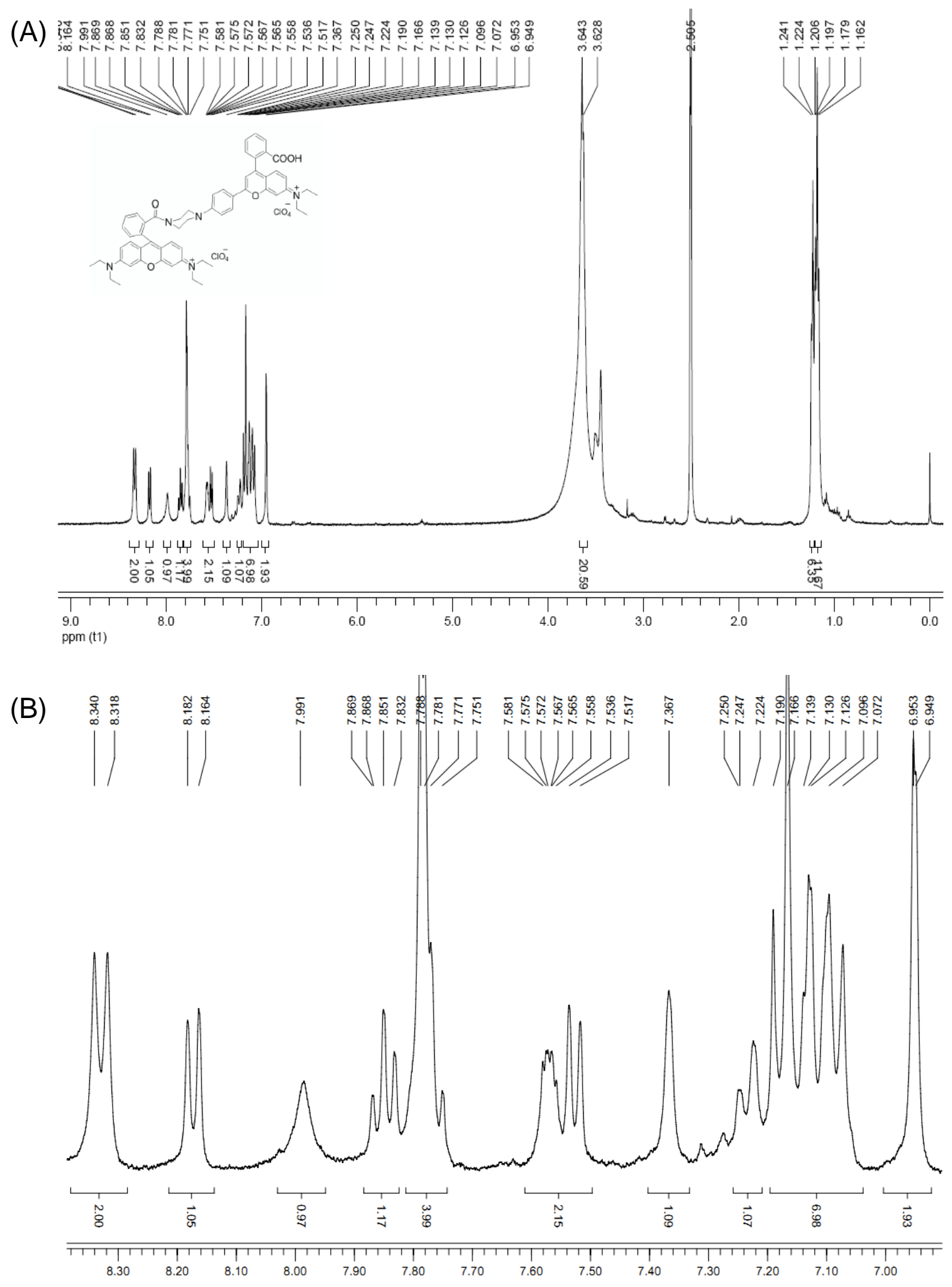

Figure S30 (A) ${ }^{1} \mathrm{H}$ NMR data of the probe $\mathbf{R h C h r}\left(\mathrm{DMSO}-d_{6}\right)$. (B) Amplified ${ }^{1} \mathrm{H}$ NMR data of the probe $\mathbf{R h C h r}$ (DMSO-d $d_{6}$ ) in the aromatic region. 

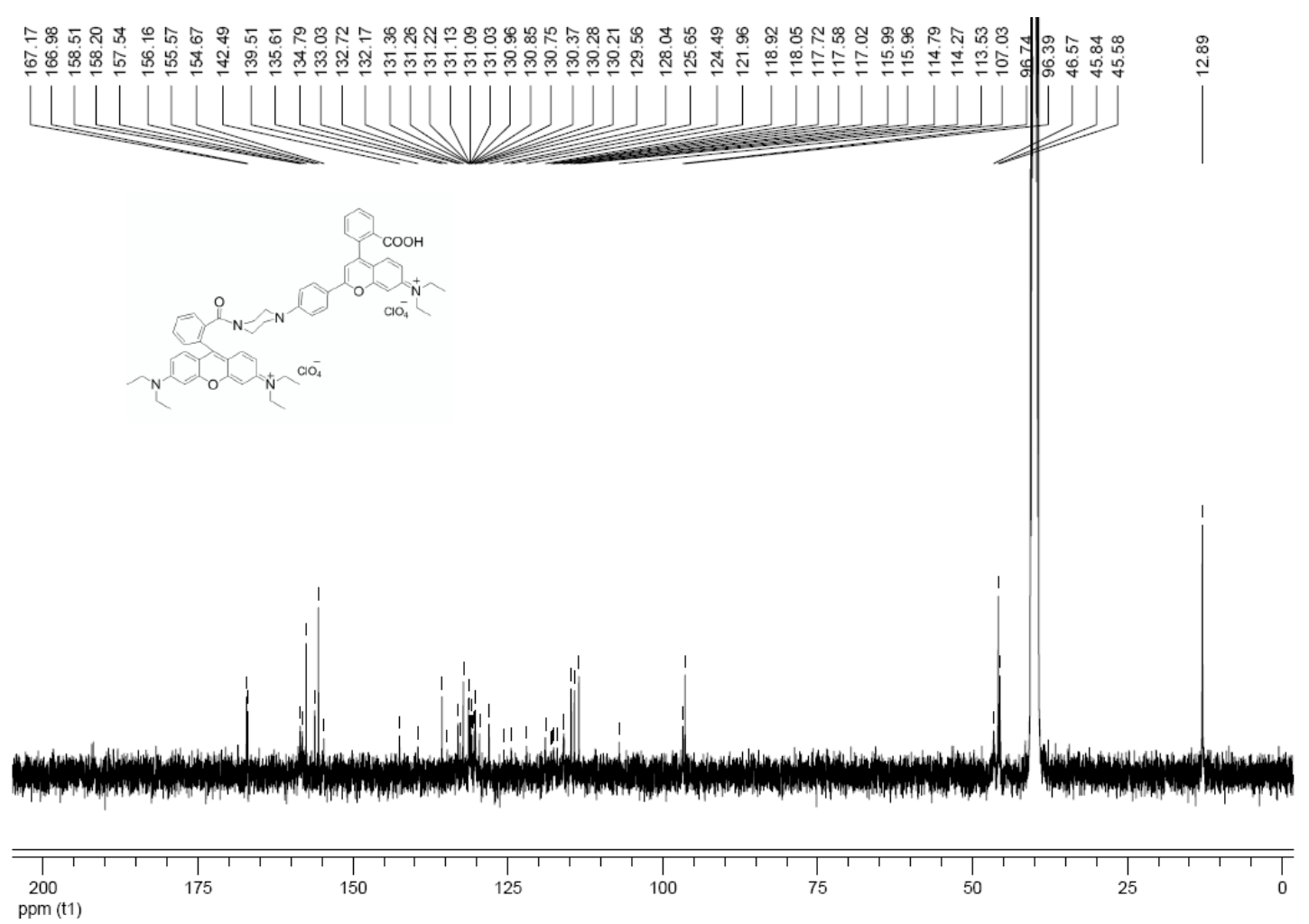

Figure S31 ${ }^{13} \mathrm{C}$ NMR data of the probe RhChr (DMSO-d 6 ).

(A) HPLC data

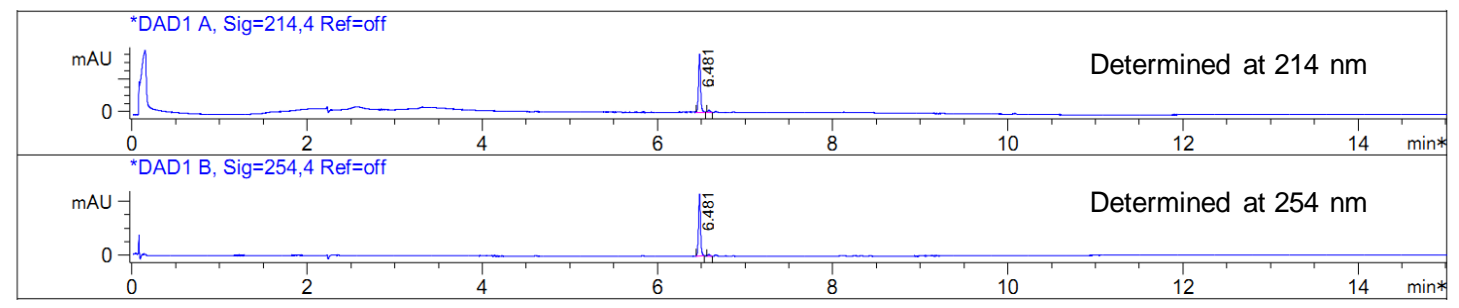

(B) MS data

Ret. Time: 6.50

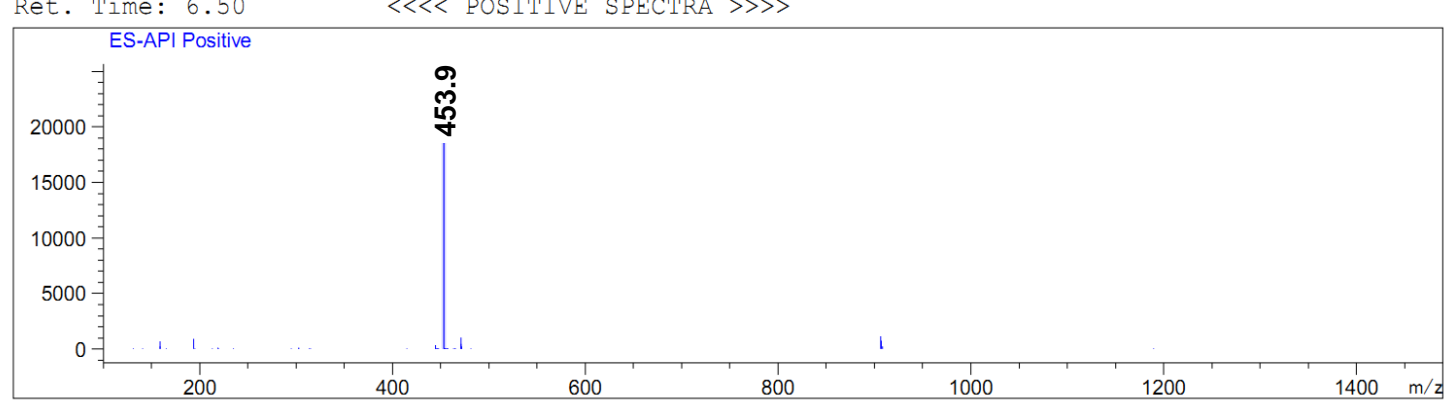

Figure S32 LC-MS data of the probe RhChr. 


\section{Reference:}

1. M. J. Frisch, G. W. Trucks, H. B. Schlegel, G. E. Scuseria, M. A. Robb, J. R. Cheeseman, G. Scalmani, V. Barone, B. Mennucci, G. A. Petersson, H. Nakatsuji, M. Caricato, X. Li, H. P. Hratchian, A. F. Izmaylov, J. Bloino, G. Zheng, J. L. Sonnenberg, M. Hada, M. Ehara, K. Toyota, R. Fukuda, J. Hasegawa, M. Ishida, T. Nakajima, Y. Honda, O. Kitao, H. Nakai, T. Vreven, J. A. Montgomery, J. E. Peralta, F. Ogliaro, M. Bearpark, J. J. Heyd, E. Brothers, K. N. Kudin, V. N. Staroverov, R. Kobayashi, J. Normand, K. Raghavachari, A. Rendell, J. C. Burant, S. S. Iyengar, J. Tomasi, M. Cossi, N. Rega, J. M. Millam, M. Klene, J. E. Knox, J. B. Cross, V. Bakken, C. Adamo, J. Jaramillo, R. Gomperts, R. E. Stratmann, O. Yazyev, A. J. Austin, R. Cammi, C. Pomelli, J. W. Ochterski, R. L. Martin, K. Morokuma, V. G. Zakrzewski, G. A. Voth, P. Salvador, J. J. Dannenberg, S. Dapprich, A. D. Daniels, O. Farkas, J. B. Foresman, J. V. Ortiz, J. Cioslowski and D. J. Fox, Gaussian, Inc., Wallingford CT, GAUSSIAN 09 (Revision A.02), Gaussian, Inc., Pittsburgh, PA, 2009. 